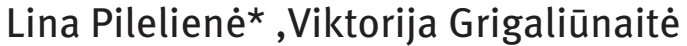

\section{The index of tourist satisfaction with Lithuania}

DOI 10.1515/ejthr-2016-0004

received March 20, 2015; accepted July 15, 2016

Abstract: During the past decades, tourism has become one of the fastest growing areas in the service sector in the world. If the aspiration is to develop a well-organised tourism industry, then fulfilment of tourist needs and wishes should be achieved. The most common technique for identifying the compatibility between tourist needs and the experience with tourism destination is tourist satisfaction measurement.

Lithuania is a small country in the northern part of Central/ Eastern Europe; the country is rarely considered as an independent tourist destination, but mostly as one of the Baltic States. Foreign tourist satisfaction is very important for the country. Considering the necessity to excel in the region, the aim of the research is to develop the index of tourist satisfaction of Lithuania.

The previously elaborated model of Lithuanian tourist satisfaction index is used as a background. The index of tourist satisfaction of Lithuania is constructed by the following stages: 1. A questionnaire research with foreign tourists, based on a theoretical model of Lithuanian Tourist Satisfaction Index, is provided; 2. The impact of model's variables on tourist satisfaction with Lithuania is determined; 3. The main variables having an impact on foreign tourist satisfaction with Lithuania are determined; and a general model of the index of tourist satisfaction of Lithuania is composed.

Keywords: Customer satisfaction, Lithuania, Satisfaction index, Tourist satisfaction.

\footnotetext{
*Corresponding author: Lina Pilelienè, Lina Pilelienė, Marketing Department, Faculty of Economics and Management, Vytautas Magnus University, S. Daukanto st. 28, LT-44246, Kaunas, Lithuania, Phone: 370-37-327856, Fax: 370-37-327857, E-mail: lina.pileliene@vdu.lt Viktorija Grigaliūnaitè, Vytautas Magnus University, Lithuania
}

\section{Introduction}

Lithuania is a small country in the northern part of Central / Eastern Europe; the country is rarely considered as an independent tourist destination, rather it is often thought of as one of the Baltic states. According to Markauskienè and Gižienè (2012), inbound tourism in Lithuania has developed over the past few decades; however, its contribution to the country's economy is significant, but insufficient. Selladurai and Sundararajan (2013) suggest that in order to develop the tourism industry, tourist satisfaction has been an important goal for many countries. Therefore, foreign tourist satisfaction is very important for Lithuania as well.

Tourism as a business includes tourism product development and tourism services, and provides a certain amount of revenue to a given country's exchequer (Markauskienè \& Gižienė, 2012). Considering the triad, the revenue actually depends on two other components: tourism product and related services. It can be argued that the two components determine the level of tourist satisfaction with a country; moreover, the excellence in these components leads to tourist loyalty. Many scholars across the world (Krešic \& Prebežac, 2011; Song et al., 2011; Al-Majali, 2012; Siri et al., 2012; Song et al., 2012, etc.) have distinguished tourism product- and service-related factors, which affect tourist satisfaction. However, our previous researches (see Pilelienė \& Grigaliūnaitè, 2014a; Grigaliūnaitè \& Pilelienè, 2014) revealed the difference in combinations of factors that have an effect on tourist satisfaction. In particular, the kind of tourism. Markauskienè and Gižienè (2012) argue that three major kinds of tourism can be distinguished: local, inbound and outbound tourism. Therefore, the problem analysed in the article is: What are the factors affecting inbound tourist satisfaction with Lithuania? Consequently, the aim of the research is to develop the index of tourist satisfaction of Lithuania.

To realise the aim of the article, the previously elaborated theoretical model of Lithuanian Tourist Satisfaction Index (Pilelienè \& Grigaliūnaitè, 2014b), is used as a background. Inbound tourists' attitudes and evaluations towards Lithuania are determined based on the research through a questionnaire. Structural equation modelling 
(SEM), using partial least squares (PLS) path modelling methodology, is applied for statistical analysis.

\section{Lithuania as a tourist destination}

Tourism does not exist as a separate and independent entity within the national accounting; moreover, tourism flows significantly vary across different geographical areas and countries. Such variations depend on many factors and are sensitive to circumstantial phenomena (Tuţă \& Micu, 2014).

Considering Lithuania as a tourist destination, various natural, political, geographical and historical factors affecting the country's popularity among tourists can be found.

Geographically, Lithuania can be considered as a country in the middle of Europe. According to World Atlas (2014), the geographical centre of Europe is located in Lithuania at $54^{\circ} 54^{\prime} \mathrm{N} 25^{\circ} 19^{\prime} \mathrm{E}$. Lithuania is bounded by the Baltic Sea on the east and has a sandy coastline. The country is small (a bit more than 65,000 square kilometres); landscape is plain, seamed with forests and numerous lakes. Considering climate, it ranges between maritime and continental, and is relatively mild: Lithuania is not characterised by hot summers, or very cold winters. The country's size and geographical position determine that the country is rarely considered as an independent tourist destination, but only as one of the Baltic states (alongside Latvia and Estonia).

Lithuania joined the international tourism market as an independent country less than quarter of century ago. Markauskienè and Gižienè (2012) emphasise that at this time Lithuania's economy has faced new changes through inbound tourism flows and tourist expenditures inside the country. Tuţă and Micu (2014) argue that Central and Eastern Europe is an area where international tourism has experienced failures attributable to the former system of centralised economy. However, nowadays the former political situation serves for Lithuania as a tourism driver. Older people from the former Soviet Union come to visit country driven by nostalgia.

Moreover, cultural properties inscribed on the World Heritage List by UNESCO can be found in Lithuania: Vilnius Historic Centre, Curonian Spit and Kernavè Archaeological Site.

According to Statistics Lithuania (2014), in 2013 (in comparison to 2012), the number of trips with overnight stay of foreign tourists increased by 5.9 percent (from 1.9 million in 2012 to 2 million in 2013). According to the
European Commission (2014), tourists mainly arrive from bordering countries: Poland, Russia, Latvia and Belarus. Further significant countries for tourism in Lithuania are Germany, the United Kingdom, Finland and Italy. In Figure 1 is presented an amount of foreign tourists by country.

The average traveller's expenditures increased only by 0.1 per cent: in 2013, foreign tourist's average expenditures was 1273 LTL (local currency at the period of the research; $1 \mathrm{EUR}=3.4528 \mathrm{LTL}$ ); total expenditure by foreign tourists in 2013 was 2.6 billion LTL ( 6 per cent more than in 2012). The total contribution of travel and tourism to the national economy exceeded 4 percent of GDP in 2011 and is forecast to rise by 4.6 percent each year until 2022 (European Commission, 2014).

\section{Theoretical model of tourist satis- faction index}

According to Markauskienė and Gižienė (2012), tourism is a very prospective economic activity involving a wide spectrum of historical, natural and cultural resources, and provides a field for employment. According to European Commission (2014), in 2011, the tourism sector in Lithuania directly involved 22,500 occupations accounting for more than 1.56 percent of total Lithuanian employment), encourages investments and forces economic development. However, to become effective, tourism-related activities have to correspond to tourist needs and requirements; in other words, tourist satisfaction has to be achieved.

Previous researches on tourist satisfaction indices (Krešic \& Prebežac, 2011; Song et al., 2011; Al-Majali, 2012; Siri et al., 2012; Song et al., 2012; etc.) enabled the determination of factors affecting tourist satisfaction, namely accommodation and catering facilities, activities in destination, natural features, destination aesthetics, environmental preservation and destination marketing; the main

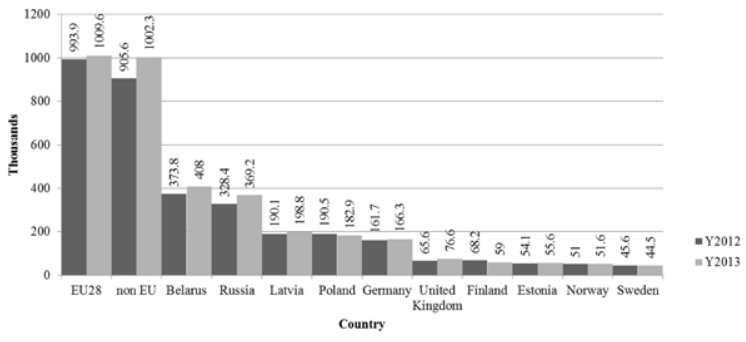

Figure 1: Foreign tourists in Lithuania by country Source: Statistics Lithuania (2014). 
consequence of satisfaction is considered to be tourist loyalty.

All the determinants of tourist satisfaction as well as its outcome (tourist loyalty) can be integrated into the tourist satisfaction index model. The structural equations representing the model are:

1. Satisfaction $=\beta_{70}+\beta_{71}$ Accommodation and catering + $\beta_{72}$ Activities in destination $+\beta_{73}$ Natural features $+\beta_{74}$ Destination aesthetics $+\beta_{75}$ Environmental preservation $+\beta_{76}$ Destination marketing $+\zeta_{7}$

2. Loyalty $=\beta_{80}+\beta_{81}$ Accommodation and catering $+\beta_{82}$ Activities in destination $+\beta_{83}$ Natural features $+\beta_{84}$ Destination aesthetics $+\beta_{85}$ Environmental preservation $+\beta_{86}$ Destination marketing $+\beta_{87}$ Satisfaction $+\zeta_{8}$

As the model is theoretical, empirical research is necessary to substantiate its application in a framework of foreign tourist satisfaction with Lithuania.

\section{Research methodology}

Considering the aim and the problem of the research, the questionnaire method of research was resorted to (the questionnaire is available from the authors upon request). The preferred measurement model was a reflective one; two to four manifest variables reflected each latent variable. During the research, a 10-point evaluation scale was applied for the questionnaire and the total sample size was 330 respondents. The survey was conducted in the summer of 2014.

Structural equation modelling (SEM), using partial least squares (PLS) path modelling methodology, was applied for statistical analysis; to uncover and treat unobserved heterogeneity, finite mixture partial least squares (FIMIX-PLS) clustering approach was provided; in order to assess whether segment-specific path coefficients differ significantly, PLS path modelling multi-group analysis (PLS-MGA) was presented.

IBM SPSS Statistics V.20, SmartPLS V.3 (Ringle et al., 2014), XLSTAT 2013 and IBM SPSS Amos V.20 software products were used for the statistical analysis of the research results.

\section{Analysis of the research results}

The analysis of the research results revealed that the theoretical index of tourist satisfaction of Lithuania contained statistically non-significant direct causal relations between latent variables. Particularly, 'accommodation and catering', 'destination aesthetics' and 'destination marketing' had no statistically significant direct effect on loyalty; the variables 'environmental preservation and natural features' had no statistically significant direct effect on satisfaction (see Table 1). Consequently, these direct relations were eliminated from the model and this led to the creation of the new PLS Path model.

All of the indicators that made up the measurement model of the new PLS path model were assessed as reliable due to the indicators' loadings being above 0.7 and statistically significant. Moreover, measurement model was considered as displaying sufficient degree of convergent validity based on average variance extracted (AVE) values being above 0.5 .

As composite reliability measure does not assume that all indicators are equally reliable and prioritise indicators according to their reliability during model estimation, latter measure was estimated for evaluating internal consistency reliability of the measurement model. All of the composite reliability values were higher than 0.7 (see Table 2); thus the internal consistency reliability of the measurement model was sufficient.

Discriminant validity of the measurement model was evaluated based on two criteria: cross loadings and Fornell-Larcker criterion. Regarding cross loadings, all indicators' loadings with their corresponding latent constructs were higher than their loadings with all the remaining constructs. Regarding Fornell-Larcker criterion, each construct's squared root AVE value was higher than its correlations with other latent variables (see Table 3). Thus, latent constructs share more variance with their assigned indicators than with another latent variable in the structural model. Consequently, the validity of the individual indicators and of the constructs was proved.

The standardised root mean square residual (SRMR) value is equal to 0.04 , thus model predictions match the data good enough. $R$-square values of variables 'satisfaction' and 'loyalty' are respectively 43 and 40 percent; hence, the proportion of variance explained by the fit regarding these variables is sufficient. Moreover, all cross-validated redundancy values (Stone-Geissers' $Q^{2}$ ) 
Table 1: Path Coefficients and their significances at the theoretical model

\begin{tabular}{|c|c|c|}
\hline Variables & $\begin{array}{l}\text { Path } \\
\text { Coefficient }\end{array}$ & $\begin{array}{l}\text { Standard } \\
\text { Error }\end{array}$ \\
\hline $\begin{array}{l}\text { Accommodation and Catering } \\
\text {->Loyalty }\end{array}$ & 0.064 & 0.053 \\
\hline $\begin{array}{l}\text { Accommodation and Catering -> } \\
\text { Satisfaction }\end{array}$ & 0.163 & 0.050 \\
\hline Activities in Destination $>>$ Loyalty & 0.137 & 0.050 \\
\hline $\begin{array}{l}\text { Activities in Destination } \\
\text {->Satisfaction }\end{array}$ & 0.149 & 0.052 \\
\hline Destination Aesthetics -> Loyalty & 0.045 & 0.047 \\
\hline Destination Aesthetics $->$ Satisfaction & 0.181 & 0.049 \\
\hline Destination Marketing -> Loyalty & 0.090 & 0.051 \\
\hline Destination Marketing -> Satisfaction & 0.292 & 0.049 \\
\hline Environmental Preservation -> Loyalty & 0.133 & 0.059 \\
\hline $\begin{array}{l}\text { Environmental Preservation -> } \\
\text { Satisfaction }\end{array}$ & 0.080 & 0.059 \\
\hline Natural Features ->Loyalty & 0.236 & 0.050 \\
\hline Natural Features ->Satisfaction & 0.054 & 0.054 \\
\hline $\begin{array}{l}\text { Satisfaction ->Loyalty } \\
\text { Table 2: Composite Reliability and AVE }\end{array}$ & 0.175 & 0.052 \\
\hline Variables & $\begin{array}{l}\text { Composite } \\
\text { Reliability }\end{array}$ & AVE \\
\hline Accommodation and Catering & 0.784 & 0.645 \\
\hline Activities in Destination & 0.800 & 0.571 \\
\hline Destination Aesthetics & 0.771 & 0.628 \\
\hline Destination Marketing & 0.786 & 0.647 \\
\hline Environmental Preservation & 0.785 & 0.647 \\
\hline Loyalty & 0.814 & 0.687 \\
\hline Natural Features & 0.812 & 0.683 \\
\hline Satisfaction & 0.765 & 0.619 \\
\hline
\end{tabular}

for endogenous latent variables are above zero (see Table 4). Consequently, the model exhibits predictive relevance. Furthermore, predictors' variables' variance inflation factor (VIF) is lower than 5; therefore, there is no multicollinearity.

All of the exogenous variables' effect sizes on the endogenous variables range from small to average. The highest effect size is created by variable 'destination marketing' to variable 'satisfaction'. The smallest effect size is created by variable 'environmental preservation' to variable 'loyalty'. Despite this, later effect size is above 0.02 and the beta of this relation is significant, implying that this effect is meaningful.

Path coefficients and their statistical significances are provided in Table 5. The variables 'accommodation and catering', 'activities in destination', 'destination aesthetics' and 'destination marketing' have direct, positive and statistically significant influences on variable 'satisfaction'. The variables 'activities in destination', 'environmental preservation', 'natural features' and 'satisfaction' have direct, positive and statistically significant influences on the variable 'loyalty'.

Besides the direct effects between variables, all of the total effects in the model are statistically significant as well (see Table 6). Even though variables 'accommodation and catering', 'destination aesthetics' and 'destination marketing' have no direct statistically significant effects on 'loyalty', these variables have statistically significant total effects on variable 'loyalty'. Furthermore, the variable 'activities in destination' affects 'loyalty' directly as well as indirectly through variable 'satisfaction'. Thus the total effect of 'activities in destination' on 'loyalty' is higher than direct effect. As the path coefficient between variables 'activities in destination' and 'loyalty' is reduced when the indirect path via variable 'satisfaction' is introduced in the model, it could be stated that 'satisfaction' became a mediator variable.

To uncover and treat the unobserved heterogeneity, finite mixture partial least squares (FIMIX-PLS) clustering approach was applied. The results of FIMIX-PLS were 
Table 3: Fornell-Larcker criterion

\begin{tabular}{|c|c|c|c|c|c|c|c|c|}
\hline Variables & 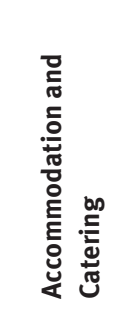 & 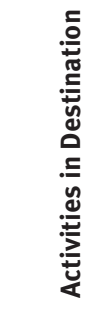 & 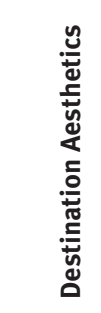 & 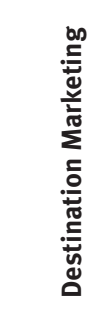 & 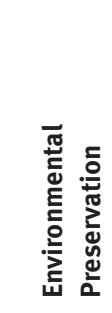 & 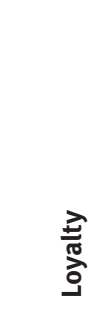 & 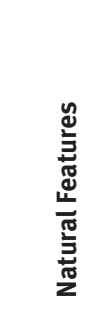 & 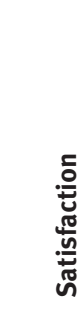 \\
\hline Accommodation and Catering & 0.803 & - & - & - & - & - & - & - \\
\hline Activities in Destination & 0.490 & 0.756 & - & - & - & - & - & - \\
\hline Destination Aesthetics & 0.317 & 0.355 & 0.792 & - & - & - & - & - \\
\hline Destination Marketing & 0.349 & 0.392 & 0.381 & 0.805 & - & - & - & - \\
\hline Environmental Preservation & 0.417 & 0.378 & 0.503 & 0.384 & 0.804 & - & - & - \\
\hline Loyalty & 0.413 & 0.451 & 0.399 & 0.410 & 0.462 & 0.829 & - & - \\
\hline Natural Features & 0.438 & 0.428 & 0.438 & 0.361 & 0.496 & 0.512 & 0.827 & - \\
\hline Satisfaction & 0.454 & 0.461 & 0.461 & 0.526 & 0.434 & 0.490 & 0.413 & 0.787 \\
\hline
\end{tabular}

Table 4: R Square, f Square, Q Square and VIF values

\begin{tabular}{|c|c|c|c|c|c|c|}
\hline Variables & $R$ Square & $\begin{array}{l}\text { f Square } \\
\text { Loyalty }\end{array}$ & $\begin{array}{l}\text { f Square } \\
\text { Satisfaction }\end{array}$ & VIF Loyalty & VIF Satisfaction & $Q$ Square \\
\hline Accommodation and Catering & - & - & 0.048 & - & 1.391 & - \\
\hline Activities in Destination & - & 0.034 & 0.033 & 1.412 & 1.463 & - \\
\hline Destination Aesthetics & - & - & 0.069 & - & 1.263 & - \\
\hline Destination Marketing & - & - & 0.126 & - & 1.315 & - \\
\hline Environmental Preservation & - & 0.032 & - & 1.471 & - & - \\
\hline Loyalty & 0.401 & - & - & - & - & 0.2569 \\
\hline Natural Features & & 0.076 & - & 1.497 & - & - \\
\hline Satisfaction & 0.430 & - & - & 1.451 & - & 0.2641 \\
\hline
\end{tabular}

Table 5: Path Coefficients and their statistical significances at the global model

\begin{tabular}{|c|c|c|c|c|c|c|}
\hline Variables & $\begin{array}{l}\text { Path } \\
\text { Coefficient }\end{array}$ & $\begin{array}{l}\text { Standard } \\
\text { Error }\end{array}$ & $\begin{array}{l}\text { Confidence } \\
\text { Interval Low }\end{array}$ & $\begin{array}{l}\text { Confidence } \\
\text { Interval Up }\end{array}$ & $T$ Statistics & $p$ Values \\
\hline $\begin{array}{l}\text { Accommodation and Catering } \\
\text {-> Satisfaction }\end{array}$ & 0.195 & 0.050 & 0.106 & 0.304 & 3.855 & 0.000 \\
\hline $\begin{array}{l}\text { Activities in Destination -> } \\
\text { Loyalty }\end{array}$ & 0.170 & 0.048 & 0.077 & 0.259 & 3.520 & 0.000 \\
\hline $\begin{array}{l}\text { Activities in Destination -> } \\
\text { Satisfaction }\end{array}$ & 0.166 & 0.048 & 0.071 & 0.263 & 3.472 & 0.001 \\
\hline $\begin{array}{l}\text { Destination Aesthetics -> } \\
\text { Satisfaction }\end{array}$ & 0.223 & 0.046 & 0.132 & 0.309 & 4.911 & 0.000 \\
\hline $\begin{array}{l}\text { Destination Marketing -> } \\
\text { Satisfaction }\end{array}$ & 0.308 & 0.048 & 0.208 & 0.394 & 6.421 & 0.000 \\
\hline $\begin{array}{l}\text { Environmental Preservation } \\
\text {-> Loyalty }\end{array}$ & 0.169 & 0.053 & 0.075 & 0.267 & 3.191 & 0.002 \\
\hline Natural Features -> Loyalty & 0.261 & 0.050 & 0.162 & 0.351 & 5.259 & 0.000 \\
\hline Satisfaction $->$ Loyalty & 0.231 & 0.052 & 0.127 & 0.325 & 4.453 & 0.000 \\
\hline
\end{tabular}


Table 6: Total effects and their statistical significances

\begin{tabular}{|c|c|c|c|c|c|c|}
\hline Variables & $\begin{array}{l}\text { Total } \\
\text { effects }\end{array}$ & Standard Error & $\begin{array}{l}\text { Confidence Interval } \\
\text { Low }\end{array}$ & $\begin{array}{l}\text { Confidence } \\
\text { Interval Up }\end{array}$ & $T$ Statistics & $p$ Values \\
\hline $\begin{array}{l}\text { Accommodation and Catering } \\
\text {-> Loyalty }\end{array}$ & 0.045 & 0.016 & 0.079 & 0.020 & 2.889 & 0.004 \\
\hline $\begin{array}{l}\text { Accommodation and Catering } \\
\text {-> Satisfaction }\end{array}$ & 0.195 & 0.050 & 0.305 & 0.106 & 3.855 & 0.000 \\
\hline $\begin{array}{l}\text { Activities in Destination -> } \\
\text { Loyalty }\end{array}$ & 0.208 & 0.048 & 0.302 & 0.117 & 4.369 & 0.000 \\
\hline $\begin{array}{l}\text { Activities in Destination -> } \\
\text { Satisfaction }\end{array}$ & 0.166 & 0.048 & 0.267 & 0.072 & 3.472 & 0.001 \\
\hline $\begin{array}{l}\text { Destination Aesthetics -> } \\
\text { Loyalty }\end{array}$ & 0.052 & 0.016 & 0.083 & 0.024 & 3.185 & 0.002 \\
\hline $\begin{array}{l}\text { Destination Aesthetics -> } \\
\text { Satisfaction }\end{array}$ & 0.223 & 0.046 & 0.313 & 0.134 & 4.911 & 0.000 \\
\hline $\begin{array}{l}\text { Destination Marketing } \\
\text {->Loyalty }\end{array}$ & 0.071 & 0.021 & 0.111 & 0.034 & 3.415 & 0.001 \\
\hline $\begin{array}{l}\text { Destination Marketing -> } \\
\text { Satisfaction }\end{array}$ & 0.308 & 0.048 & 0.396 & 0.213 & 6.421 & 0.000 \\
\hline $\begin{array}{l}\text { Environmental Preservation } \\
->\text { Loyalty }\end{array}$ & 0.169 & 0.053 & 0.268 & 0.075 & 3.191 & 0.002 \\
\hline Natural Features -> Loyalty & 0.261 & 0.050 & 0.353 & 0.162 & 5.259 & 0.000 \\
\hline Satisfaction -> Loyalty & 0.231 & 0.052 & 0.326 & 0.127 & 4.453 & 0.000 \\
\hline
\end{tabular}

Table 7: Information and classification criteria for varying number of segments

\begin{tabular}{llll}
\hline \multicolumn{2}{l}{ Criteria } & \multicolumn{2}{c}{ Number of Segments } \\
& $\mathbf{k}=\mathbf{2}$ & $\mathbf{k}=\mathbf{3}$ & $\mathbf{k}=\mathbf{4}$ \\
\hline AIC (Akaike's Information Criterion) & 1769.5920 & 1835.5936 & 1997.7188 \\
BIC (Bayesian Information Criteria) & 1849.3729 & 1957.1645 & 2161.0798 \\
CAIC (Consistent AIC) & 1849.4365 & 1957.2614 & 2161.2099 \\
EN (Normed Entropy Statistic) & 0.5522 & 0.4847 & 0.4754 \\
\hline
\end{tabular}

computed for two, three and four segments. A comparison of the segment-specific information and classification criteria is presented in Table 7. The analysis of these criteria reveals that the choice of two segments is appropriate for customer segmentation purposes. All information criteria increase and classification criterion decreases considerably in the ensuing numbers of classes. Moreover, each additional segment contains only a very small sample size.

Thus, observations were assigned to each segment according to their segment membership's maximum probability. The first segment represents 22.7 percent of the total sample, while the second segment represents 77.3 percent of the total sample.

Consequently, it could be stated that overall set of observations consists of a large, stable segment and a small fuzzy one.
Before evaluating inner model relationships, both segment-specific models were tested with regard to reliability and discriminant validity. Furthermore, the statistical significance of path coefficients was assessed.

The large, stable segment is segment number two and it contains 77.3 percent of the total sample. $R$-square values regarding this segment are substantial: $R$-square value of variable 'loyalty' is 52.1 percent; $R$-square value of variable 'satisfaction' is 52.8 percent. Thus, latter model has higher $R$-square values than the global model. Nevertheless, path coefficients in both global and segment No. 2 models are positive and statistically significant. Moreover, the highest influence on 'satisfaction' in both models is made by variable 'destination marketing'. Contrarily, the variable 'natural features' has the highest influence on 'loyalty' in the global model, while in the segment No. 2 model 'loyalty' is most strongly influenced 
by variable 'satisfaction' (see Table 8). Despite this, all the remaining relations in these models are relatively similar, thus it could be stated that global model substantiates and corresponds to segment No. 2 model and their incorporation leads to the formation of the new general model.

On the other hand, segment No. 1 is the small fuzzy one. It contains only 22.7 percent of the total sample. $R$-square values regarding this segment are 43.5 percent of variable 'loyalty', 57 percent of variable 'satisfaction'. The latter model contains only two statistically significant path coefficients - 'destination aesthetics' statistically significantly influences satisfaction and 'natural features' statistically significantly influence 'loyalty' (see Table 8).

However, only significant differences between the segments offer valuable interpretations. Thus, in order to assess whether segment-specific path coefficients differ significantly, PLS path modelling multi-group analysis (PLS-MGA) was applied. Consequently, as shown in the fourth column of Table 8 ( $T$ value for multi-group comparison test), four paths differ significantly between segment No. 1 model and segment No. 2 model. Thus, consumers in each segment exhibit significantly different drivers with respect to their satisfaction as well as loyalty. Particularly, the variable 'destination aesthetics' has low influence on 'satisfaction' concerning segment No. 2 model and very high influence on 'satisfaction' concerning segment No. 1 model. Furthermore, variable 'destination marketing' has a very high influence on 'satisfaction' with reference to segment No. 2 model and low, negative, statistically non-significant influence on 'satisfaction' with reference to segment No. 1 model. Moreover, the variables 'environmental preservation' and 'satisfaction' have negative and statistically non-significant effects on 'loyalty' regarding segment No. 1 model, while the same variables have high, positive and statistically significant effects on 'loyalty' regarding segment No. 2 model.

Consequently, it could be stated that incorporation of the global model with the segment No. 2 model leads to the formation of the final general model of the index of tourist satisfaction of Lithuania, which covers nearly 80 percent of the total sample. In addition, segment No. 1 model leads to the formation of the exceptional model and significant differences between these models allow differentiated marketing activities to satisfy varying customers' expectations better.

\section{Discussion}

Incorporation of the global model with the segment No. 2 model led to the formation of the general model of the index of tourist satisfaction of Lithuania, covering nearly 80 percent of the total sample, which is presented in Figure 2. As it can be seen, 'accommodation and catering', 'destination aesthetics' and 'destination marketing' directly, positively and significantly affect tourists' satisfaction with Lithuania. The most important determinant of foreign tourists' satisfaction with Lithuania is 'destination marketing'. Moreover, 'activities in destination' positively and directly influence 'satisfaction' as well as 'loyalty'. Additionally, foreign tourists' 'loyalty' to

Table 8: Path coefficients by segments

\begin{tabular}{|c|c|c|c|}
\hline Variables & $\begin{array}{l}\text { Path Coefficients } \\
\text { Segment } 1 \\
\text { (Segment size = } 22.7 \% \text { ) }\end{array}$ & $\begin{array}{l}\text { Segment } 2 \\
\text { (Segment size = } 77.3 \% \text { ) }\end{array}$ & $T$ (Multi-Group Analysis) \\
\hline $\begin{array}{l}\text { Accommodation and Catering } \\
\text {->Satisfaction }\end{array}$ & 0.082 & $0.181^{\star}$ & 0.858 \\
\hline Activities in Destination ->Loyalty & 0.209 & $0.193^{*}$ & 0.052 \\
\hline Activities in Destination ->Satisfaction & 0.129 & $0.165^{\star}$ & 0.202 \\
\hline Destination Aesthetics ->Satisfaction & $0.584^{\star}$ & $0.123^{*}$ & $3.899^{*}$ \\
\hline Destination Marketing ->Satisfaction & -0.158 & $0.487^{\star}$ & $2.460^{*}$ \\
\hline Environmental Preservation ->Loyalty & -0.445 & $0.267^{\star}$ & $2.830^{\star}$ \\
\hline Natural Features ->Loyalty & $0.606^{*}$ & $0.187^{*}$ & 1.477 \\
\hline Satisfaction ->Loyalty & -0.415 & $0.303^{*}$ & $2.959^{\star}$ \\
\hline $\mathrm{R}^{2}$ Loyalty & 0.435 & 0.521 & - \\
\hline $\mathrm{R}^{2}$ Satisfaction & 0.570 & 0.528 & - \\
\hline
\end{tabular}

${ }^{*} p<0.05$ 


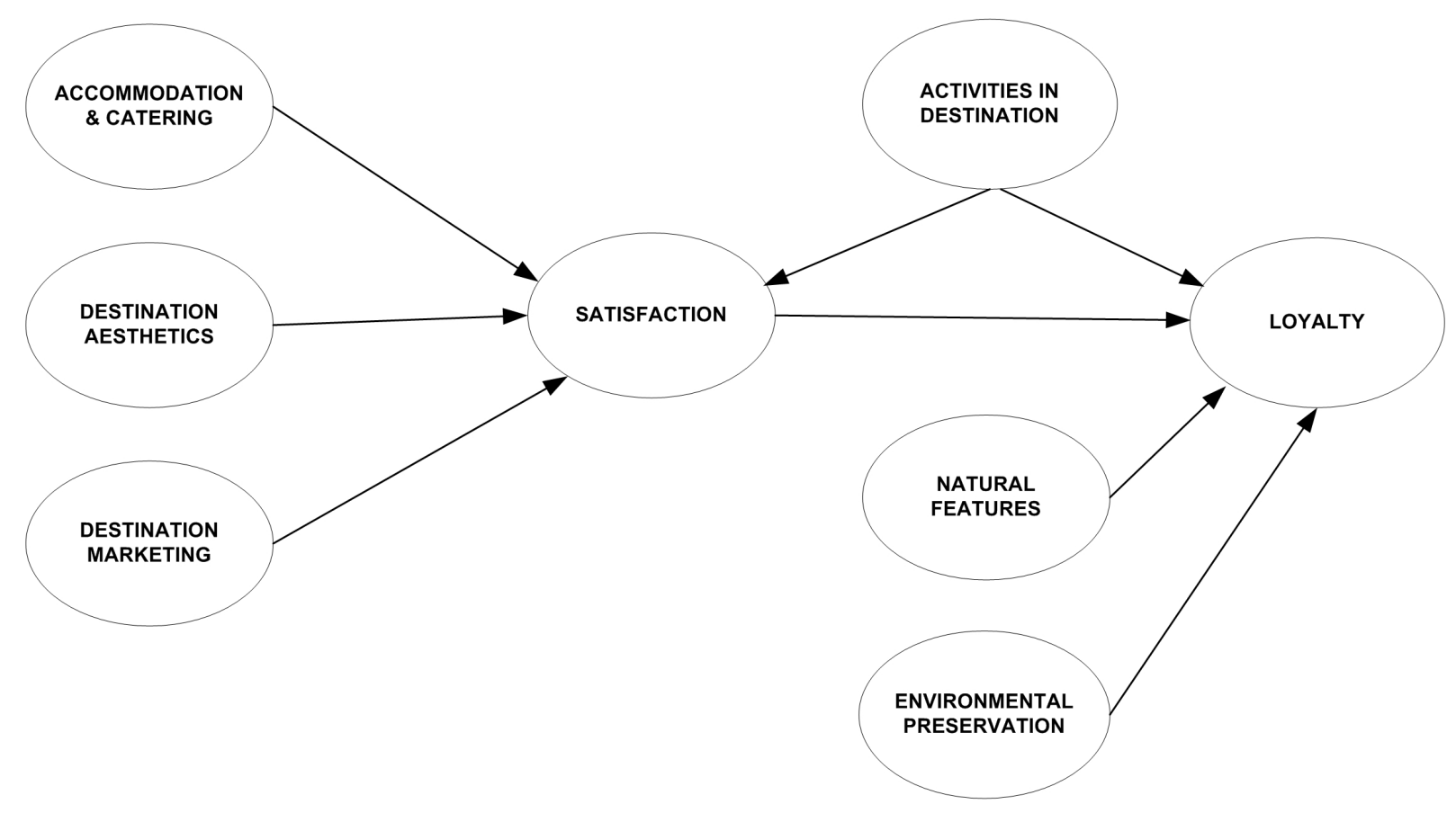

Figure 2: General Model of the Index of Tourist Satisfaction with Lithuania

Lithuania as tourism destination is influenced by 'natural features', 'environmental preservation' and tourists' 'satisfaction' (the latter variable is the most important determinant of tourists' 'loyalty').

Thus, the sequence of relations 'destination marketing' - 'satisfaction' - 'loyalty' becomes the base for strategies aiming at enhancing foreign tourists' 'satisfaction' as well as 'loyalty' to Lithuania as a tourists' destination.

As Lithuania is rarely considered as an independent tourist destination, rather one of the Baltic states, one of the 'destination marketing' indicators', which becomes crucial in this case, is positioning Lithuania as an exclusive, unique and independent tourists' destination.

On the other hand, there is one small fuzzy tourists' segment, in which relation 'destination marketing' - 'satisfaction' - loyalty' could not be applied in order to enhance tourists' 'satisfaction' and 'loyalty', because 'destination marketing' has no significant influence on 'satisfaction' as well as 'satisfaction' has no significant influence on 'loyalty'. In this case, the exceptional model is formed: tourists' loyalty is influenced by 'natural features'; tourists' 'satisfaction' is influences by 'destination aesthetics'. As 'natural features' usually require large investments from the government, this variable is considered as constant in the model. Thus, in order to present recommendations with regard to this segment and later variable, further researches must be provided. Alternatively, with the aim of enhancing 'satisfaction' concerning this segment, 'destination aesthetics' has to be improved.

As explanatory variables that best characterise the two uncovered tourists' segments are not assessed, the main investments' saving mean that could enhance tourists' 'satisfaction' and 'loyalty' to Lithuania as tourists' destination is joint improvement of 'destination marketing' and 'destination aesthetics'. Consequently, most important determinants of tourists' satisfaction with regard to both segments would be superior and this would lead Lithuania to excel in the region.

\section{Conclusions}

Lithuania is rarely considered as an independent tourist destination, rather only as one of the Baltic states. Thus, there exists necessity for Lithuania to excel in the region, because travel and tourism industry contribute to the national economy. For this reason, foreign tourist satisfaction is very important for the country. So far, tourists mainly arrive from bordering countries: Poland, Russia, Latvia and Belarus. Further significant countries for tourism in Lithuania are Germany, the United Kingdom, Finland and Italy.

The analysis of the research results revealed that foreign tourists in Lithuania can be divided into a large, 
stable segment and a small fuzzy one. Incorporation of the elaborated global model with the large, stable segment's model led to the formation of the general model of the index of tourist satisfaction of Lithuania. Consequently, it can be stated that 'accommodation and catering', 'destination aesthetics' and 'destination marketing' affect tourists' satisfaction with Lithuania. The most important determinant of foreign tourists' satisfaction with Lithuania is 'destination marketing'. Moreover, 'activities in destination' influence 'satisfaction' as well as 'loyalty'. Additionally, foreign tourists' 'loyalty' to Lithuania as tourism destination is influenced by 'natural features', 'environmental preservation' and tourists' 'satisfaction', which is the most important determinant of tourists' 'loyalty'.

The sequence of relations 'destination marketing' - 'satisfaction' - 'loyalty' becomes the base for strategies aiming at enhancing foreign tourists' 'satisfaction' as well as 'loyalty' to Lithuania as tourist destination. The crucial indicator with regard to 'destination marketing' is positioning Lithuania as an exclusive, unique and independent tourist destination. Furthermore, with the aim of enhancing 'satisfaction' concerning both segments, 'destination aesthetics' has to be improved as well. Consequently, improving determinants against other Baltic states would lead Lithuania to excel in the region.

\section{References}

[1] Al-Majali, M. M. (2012). International Tourists Satisfaction: Case of Jordan. International Business Research, 5(9), 210-216.

[2] European Commission (2014). Tourism industry sub-sectors. Country report: Lithuania. Internet access: http://ec.europa. eu/enterprise/sectors/tourism/tourism-business-portal/ documents/business/internationalisation/lithuania_country_ report.pdf [Accessed October 8, 2014].

[3] Grigaliūnaitė, V., \& Pilelienė, L. (2014). Rural Tourist Satisfaction Index: A Case of Lithuania. Materials of 20th Annual International Scientific Conference "Research for Rural Development 2014”, Jelgava (Forthcoming).

[4] Krešic, D., \& Prebežac, D. (2011). Index of destination attractiveness as a tool for destination attractiveness assessment. TOURISM - An International Interdisciplinary Journal, 59(4), 497-517.

[5] Markauskienè, A., \& Gižienè, V. (2012). Atvykstamojo turizmo poveikis šalies ekonomikai. (Lithuanian). Economics \& Management, 17(3), 1003-1009.

[6] Pilelienė, L., \& Grigaliūnaitè, V. (2014a). Lithuanian tourist satisfaction index model. European Journal of Tourism, Hospitality and Recreation, 5(1), 35-51.

[7] Pilelienè, L., \& Grigaliūnaitè, V. (2014b). Lietuvos turistu pasitenkinimo indekso modelis: teorinès j̨žvalgos. (Lithuanian). Organizacijų vadyba: sisteminiai tyrimai, 69, 107-118.
[8] Ringle, Ch. M., Wende, S, \& Becker, J.-M. (2014). Smartpls 3. Hamburg: SmartPLS. Retrieved from http://www.smartpls.com.

[9] Selladurai, M. M., \& Sundararajan, K. K. (2013). A Study On Satisfaction Of Tourists Visiting Yercaud Of Salem District. Asia Pacific Journal Of Research In Business Management, 4(3), 1.

[10] Siri, R., Josiam, B., Kennon, L., \& Spears, D. (2012). Indian Tourists' Satisfaction of Bangkok, Thailand. Journal of Services Research, 12(1), 25-42.

[11] Song, H., Li, G., van der Veen, R., \& Chen, J. L. (2011). Assessing Mainland Chinese Tourists' Satisfaction with Hong Kong Using Tourist Satisfaction Index. International Journal of Tourism Research, 13(1), 82-96.

[12] Song, H., van der Veen, R., Li, G., \&Chen, J., L. (2012). The Hong Kong tourist satisfaction index. Annals of Tourism Research, 39(1), 459-479.

[13] Statistics Lithuania (2014). Inbound tourism 2013. Internet access: http://osp.stat.gov.lt/pranesimaispaudai?articleld=2652830 [Accessed October 8, 2014].

[14] Tuţă, L., \& Micu, C. (2014). Analysing Tourism Flow Indicators in Central and Eastern Europe. Agricultural Management / Lucrari Stiintifice Seria I, Management Agricol, 16(4), 58-64.

[15] World Atlas (2014). Internet access: http://www.worldatlas. com/webimage/countrys/eulandst.htm [Accessed October 8, 2014].

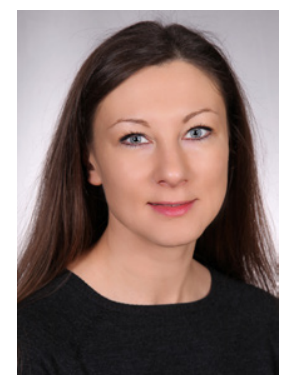

Lina Pilelienè, Ph.D., Associated Professor at Marketing Department, Faculty of Economics and Management, Vytautas Magnus University, S. Daukantost. 28, Kaunas 44246, Lithuania, Phone: +370 37 327856, +370 656 65114; Fax: +370 37 327857; E-mail: lina.pileliene@vdu.lt. Lina Pilelienè specialises in marketing. During her academic career, she has published more than 40 articles in scholarly journals (referred in scientific databases), participated and presented her research findings at more than twenty international scientific events in Lithuania, Russia, Ukraine, Finland, Moldova, Portugal, Czech Republic, Slovakia, Poland and Latvia. Her main scientific research areas are consumer behaviour, customer satisfaction and loyalty, place marketing and neuro marketing.

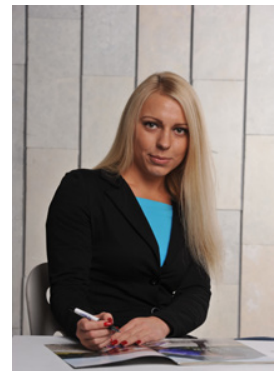

Viktorija Grigaliūnaitè, $\mathrm{PhD}$ student at Marketing Department, Faculty of Economics and Management, Vytautas Magnus University, S. Daukanto st. 28, Kaunas 44246, Lithuania, Phone: +370 37 327856; Fax: +370 37 327857; E-mail: viktorija.grigaliunaite@vdu.lt. Viktorija Grigaliūnaitè is an assistant professor and specialist researcher at Vytautas Magnus University. She focuses on investigating 
the various phenomena in marketing area by applying mathematical methods. She has participated in international scientific conferences in Lithuania and abroad. Her main scientific research areas are customer satisfaction and loyalty, mathematical methods in marketing, neuro marketing. 